\title{
Stakelama pacifica gen. nov., sp. nov., a new member of the family Sphingomonadaceae isolated from the Pacific Ocean
}

\section{Correspondence \\ Nianzhi Jiao \\ Jiao@xmu.edu.cn}

\author{
Chuang Chen, ${ }^{1}$ Qiang Zheng, ${ }^{1}$ Ya-Nan Wang, ${ }^{1,2}$ Xiao-Jun Yan, ${ }^{3}$ \\ Li-Kai Hao, ${ }^{1}$ Xun Du${ }^{2}$ and Nianzhi Jiao ${ }^{1}$ \\ ${ }^{1}$ State Key Laboratory for Marine Environmental Science, Xiamen University, Xiamen 361005, PR
China
}

${ }^{2}$ Key Laboratory of Microbial Engineering at the Institute of Biology, Henan Academy of Sciences, Zhengzhou 450008, PR China

${ }^{3}$ Key Laboratory of Applied Marine Biotechnology, Ministry of Education, Ningbo University, Ningbo 315211, PR China

\begin{abstract}
A Gram reaction-negative, weakly motile, non-spore-forming, rod-shaped, aerobic bacterium designated strain $\mathrm{JLT} 832^{\top}$ was isolated from surface water of the central Pacific Ocean and formed yellow colonies on rich organic (RO) medium. The strain was oxidase-negative and catalase-positive. Acid was produced from mannitol, glucose, sucrose, lactose, sorbitol, maltose, $(+)$-trehalose and D-fructose. No acid was produced from D-(+)-xylose. The major cellular fatty acids of strain $\mathrm{JLT}_{3} 32^{\top}$ were $\mathrm{C}_{18: 1} \omega 7 c, \mathrm{C}_{14: 0} 2-\mathrm{OH}$ and $\mathrm{C}_{16: 0}$. The major polar lipids were sphingoglycolipid, diphosphatidylglycerol, phosphatidylglycerol and phosphatidylethanolamine. Ubiquinone-10 and spermidine were present as the major quinone and polyamine, respectively. The genomic DNA G $+C$ content of strain $\mathrm{JLT} 832^{\top}$ was $66.0 \pm 0.5 \mathrm{~mol} \%$. Phylogenetic analysis based on 16S rRNA gene sequences indicated that the new isolate formed a tight branch within the family Sphingomonadaceae but was clearly separate from established genera in this family. The sequence similarities between the new isolate and type strains of established genera ranged from 90.5 to $94.9 \%$. Based on these data, strain JLT832 ${ }^{\top}$ constitutes a novel genus and species, for which the name Stakelama pacifica gen. nov., sp. nov. is proposed. The type strain of Stakelama pacifica is $\mathrm{JLT} 832^{\top}$ (=CGMCC $1.7294^{\top}=$ LMG $\left.24686^{\top}\right)$.
\end{abstract}

The family Sphingomonadaceae was established by Kosako et al. (2000) and was further divided into families Sphingomonadaceae and Erythrobacteraceae by Lee et al. (2005). The genus Sphingomonas was first described by Yabuuchi et al. (1990) and was later divided into four genera, Sphingomonas, Sphingobium, Novosphingobium and Sphingopyxis (Takeuchi et al., 2001), based on both phylogenetic analysis of 16S rRNA gene sequences and chemotaxonomic and phenotypic differences. Many novel genera of this clade have been described, such as Sphingomonas, Sphingobium, Novosphingobium, Sphingopyxis,

\footnotetext{
Abbreviations: UPLC-Q-TOF-MS, ultra-performance liquid chromatography coupled with quadruple time-of-flight mass spectrometry; MR, methyl red; VP, Voges-Proskauer.

The GenBank/EMBL/DDBJ accession number for the $16 \mathrm{~S}$ rRNA gene sequence of strain JLT832 ${ }^{\top}$ is EU581829.

A transmission electron micrograph of negatively stained cells and polar lipid profiles of strain $\mathrm{JLT} 832^{\top}$ are available as supplementary material with the online version of this paper.
}

Zymomonas, Sandaracinobacter, Sphingosinicella, Sandarakinorhabdus and Blastomonas.

Strain JLT832 ${ }^{\mathrm{T}}$ was isolated from the surface of the Pacific Ocean at $174^{\circ} 21.70^{\prime}$ E $20^{\circ} 34.44^{\prime} \mathrm{N}$ and formed a deep branch within the family Sphingomonadaceae. In this study, we characterized strain $\mathrm{JLT} 832^{\mathrm{T}}$ by using a polyphasic approach.

Strain JLT832 ${ }^{\mathrm{T}}$ was initially isolated with seawater medium (SW) containing (per litre seawater filtered by $0.2 \mu \mathrm{m}$ film) $1 \mathrm{~g}$ peptone, $1 \mathrm{~g}$ yeast extract, $20 \mu \mathrm{g}$ vitamin $\mathrm{B}_{12}$ and $1 \mathrm{ml}$ of a trace element solution (ES) as described by Drews (1983). The strain was identified by growing on modified rich organic (RO) medium (Yurkov et al., 1999) containing (per litre distilled water) $1 \mathrm{~g}$ peptone, $1 \mathrm{~g}$ yeast extract, $20 \mathrm{~g}$ $\mathrm{NaCl}, 1 \mathrm{~g}$ sodium acetate, $0.3 \mathrm{~g} \mathrm{KCl}, 0.5 \mathrm{~g} \mathrm{MgSO}_{4} .7 \mathrm{H}_{2} \mathrm{O}$, $0.05 \mathrm{~g} \mathrm{CaCl}_{2} .7 \mathrm{H}_{2} \mathrm{O}, 0.3 \mathrm{~g} \mathrm{NH} \mathrm{Nl}_{4}, 0.3 \mathrm{~g} \mathrm{~K} \mathrm{~K}_{2} \mathrm{HPO}_{4}, 20 \mu \mathrm{g}$ vitamin $\mathrm{B}_{12}$ and $1.0 \mathrm{ml} \mathrm{ES}$, at $\mathrm{pH} 8.0$ and $28{ }^{\circ} \mathrm{C}$.

Cell morphology was examined using light microscopy (BX61; Olympus) and TEM (H600; Hitachi). The Gram 
reaction was tested according to standard procedures (Gerhardt et al., 1994). Catalase activity was determined by adding drops of $3 \% \mathrm{H}_{2} \mathrm{O}_{2}$ to an overnight colony and assessed by the formation of bubbles. The $\mathrm{pH}$ and temperature ranges for growth were determined by adjusting the RO medium to a final $\mathrm{pH}$ of 5.5-9.5 (at intervals of 0.5 $\mathrm{pH}$ units) with $\mathrm{HCl}$ and $\mathrm{NaOH}$, and by incubation at 0,5 , $10,15,25,28,30,37$ and $40{ }^{\circ} \mathrm{C}$. Growth in NaCl 1-6\% (w/v) (increments of $0.5 \%$ ) was investigated in RO medium. Oxidase and urease activity, hydrolysis of casein, starch, gelatin and Tween 80 and reduction of nitrate and nitrite were determined as described by Dong \& Cai (2001) on RO medium. Denitrification was tested by growing the strain anaerobically in the presence of nitrate (Zumft, 1992). $\mathrm{H}_{2} \mathrm{~S}$ production was tested as described by Bruns et al. (2001). Indole production, methyl red (MR) test and VogesProskauer (VP) reaction were determined as described by Denner et al. (2001).

The ability of strain $\mathrm{JLT} 832^{\mathrm{T}}$ to utilize substrates as sole carbon and energy sources was examined on RO medium without organic compounds at $28{ }^{\circ} \mathrm{C}$ for $7-14$ days (Williams et al., 1983). Acid production from carbohydrates was assessed using the procedures outlined by Cappuccino \& Sherman (2002). Antibiotic susceptibility was tested by using the disc-diffusion plate (Kirby-Bauer) method according to Fraser \& Jorgensen (1997) and Andrews (2008).
Cellular fatty acid composition was determined as described previously (Hu et al., 2004) by growing cells of strain $\mathrm{JLT} 832^{\mathrm{T}}$ on marine agar 2216e (MA; Difco) for 2 days at $28{ }^{\circ} \mathrm{C}$. Polyamines were extracted and derivatized as described by Busse \& Auling (1988) and analysed by HPLC using the equipment previously described by Stolz et al. (2007). Polar lipids were identified by twodimensional TLC and detection with sulfuric acid/ethanol $(1: 2, \mathrm{v} / \mathrm{v})$ followed by heating at $150{ }^{\circ} \mathrm{C}$ for $3 \mathrm{~min}$, according to the procedures described by Minnikin et al. (1984). Isoprenoid quinones were analysed as described by Hiraishi et al. (1998) using ultra-performance liquid chromatography coupled with quadruple time-of-flight mass spectrometry (UPLC-Q-TOF-MS) in an electrospray ionization method (Romano et al., 2006).

Genomic DNA was extracted following the method of Marmur (1961) from cells that were grown in RO medium for 2 days at $28{ }^{\circ} \mathrm{C}$, washed and then resuspended in the buffer. Purity was assessed by measuring absorbance at $A_{280} /$ $A_{260}$ and $A_{230} / A_{260}$ ratios (Johnson, 1994). The 16S rRNA gene was amplified and sequenced as described by Rainey et al. (1996) and sequences were aligned using the BLAST tool (http://blast.ncbi.nlm.nih.gov/Blast.cgi) (Altschul et al., 1990) to determine the approximate phylogenetic affiliation. Phylogenetic trees were constructed using neighbour-joining and maximum-parsimony algorithms in MEGA 4.0

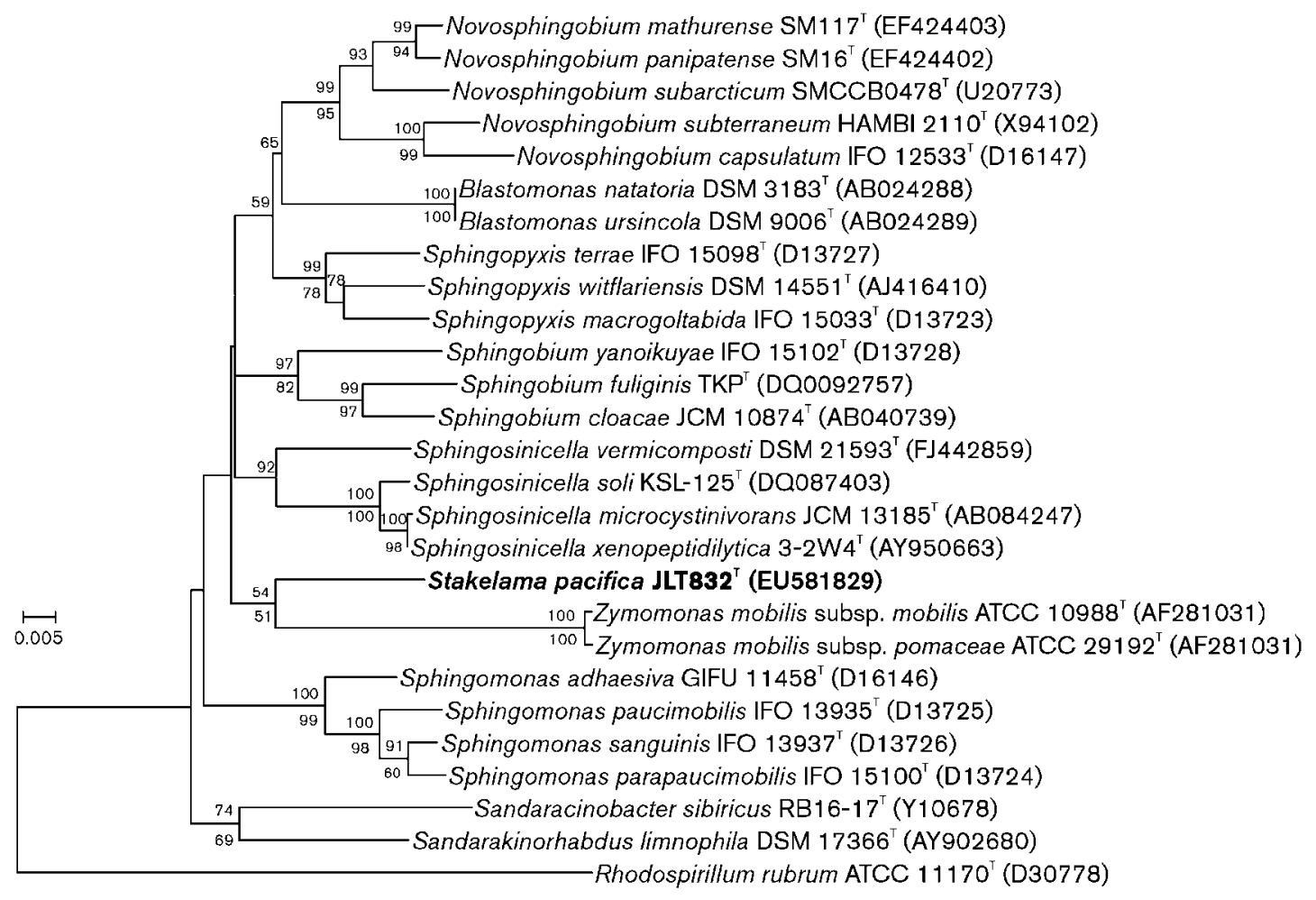

Fig. 1. Neighbour-joining phylogenetic tree based on 16S rRNA gene sequences showing the relationship between strain $\mathrm{JLT}_{3}{ }^{\top}$ and representatives of the family Sphingomonadaceae. Bootstrap percentages (above $50 \%$ ) from both neighbourjoining (above nodes) and maximum-parsimony (below nodes) are shown. Bar, 0.005 substitutions per nucleotide position. 
software (Kumar et al., 2004). DNA G + C contents were determined by thermal denaturation (Marmur \& Doty, 1962) using DNA of Escherichia coli DH5 $\alpha$ as a standard for calibration of the $T_{\mathrm{m}}$.

Strain JLT $832^{\mathrm{T}}$ cells were strictly aerobic, heterotrophic, Gram reaction-negative, short rods. Flagella were observed (Supplementary Fig. S1, available in IJSEM Online). Colonies were gold-yellow, glossy, opaque, circular and about $1 \mathrm{~mm}$ in diameter. JLT832 ${ }^{\mathrm{T}}$ grew in the presence of $0-5 \%(w / v) ~ N a C l$ (optimum $2 \%$ ), at $5-37{ }^{\circ} \mathrm{C}$ (optimum $28{ }^{\circ} \mathrm{C}$ ) and pH 6-9 (optimum pH 8). Strain JLT832 ${ }^{\mathrm{T}}$ was positive for catalase, aerobic nitrate reduction, $\mathrm{H}_{2} \mathrm{~S}$ production and VP reaction and negative for oxidase, urease, aerobic nitrite reduction, anaerobic nitrate reduction, indole production, MR test and hydrolysis of gelatin, starch, Tween 80 and casein. Acid was produced from mannitol, glucose, sucrose, lactose, sorbitol, maltose, $(+)$-trehalose and D-fructose. No acid was produced from (+)-D-xylose.

JLT832 ${ }^{\mathrm{T}}$ exhibited a polyamine pattern with the following compounds (per g dry weight): spermidine $(17.6 \mu \mathrm{mol})$, putrescine $(0.2 \mu \mathrm{mol})$, cadaverine $(0.6 \mu \mathrm{mol})$ and traces $(<0.1 \mu \mathrm{mol})$ of 1,3 -diaminopropane and spermine. This polyamine pattern was in agreement with the traits reported for the genera Blastomonas, Sphingobium, Novosphingobium and Sphingopyxis, while the presence of homospermidine was restricted in species of Zymomonas, Sphingosinicella and Sphingomonas (Busse et al., 1999; Takeuchi et al., 2001; Hamana et al., 2003). The major polar lipids were sphingoglycolipid, diphosphatidylglycerol, phosphatidylglycerol and phosphatidylethanolamine (Supplementary Fig. S2). Q-10 was the sole respiratory

Table 1. Differentiation of physiological and biochemical characteristics between strain $\mathrm{JLT}_{83}{ }^{\top}$ and closely related species within the family Sphingomonadaceae

Taxa: 1, JLT832 ${ }^{\mathrm{T}} ; 2$, Sphingosinicella microcystinivorans JCM $13185^{\mathrm{T}} ; 3$, Sphingosinicella xenopeptidilytica DSM $17130^{\mathrm{T}} ; 4$, Sphingosinicella soli DSM $17328^{\mathrm{T}}$; 5, Novosphingobium panipatense CCM $7472^{\mathrm{T}} ; 6$, Novosphingobium mathurense CCM $7473^{\mathrm{T}} ; 7$, Novosphingobium subarcticum SMCC B0478 ${ }^{\mathrm{T}}$; 8, Zymomonas species. Data in columns were taken from the following sources: 1-4, Maruyama et al. (2006), Geueke et al. (2007) and Yoon et al. (2008); 5-6, Gupta et al. (2009); 7, Nohynek et al. (1996) and Lim et al. (2007); 8, De Ley \& Swings (1976) and Swings \& De Ley (1977). All strains were negative for Gram stain, gelatin hydrolysis and indole production. Q-10 was the respiratory quinone for all the strains. w, Weak reaction; ND, no data.

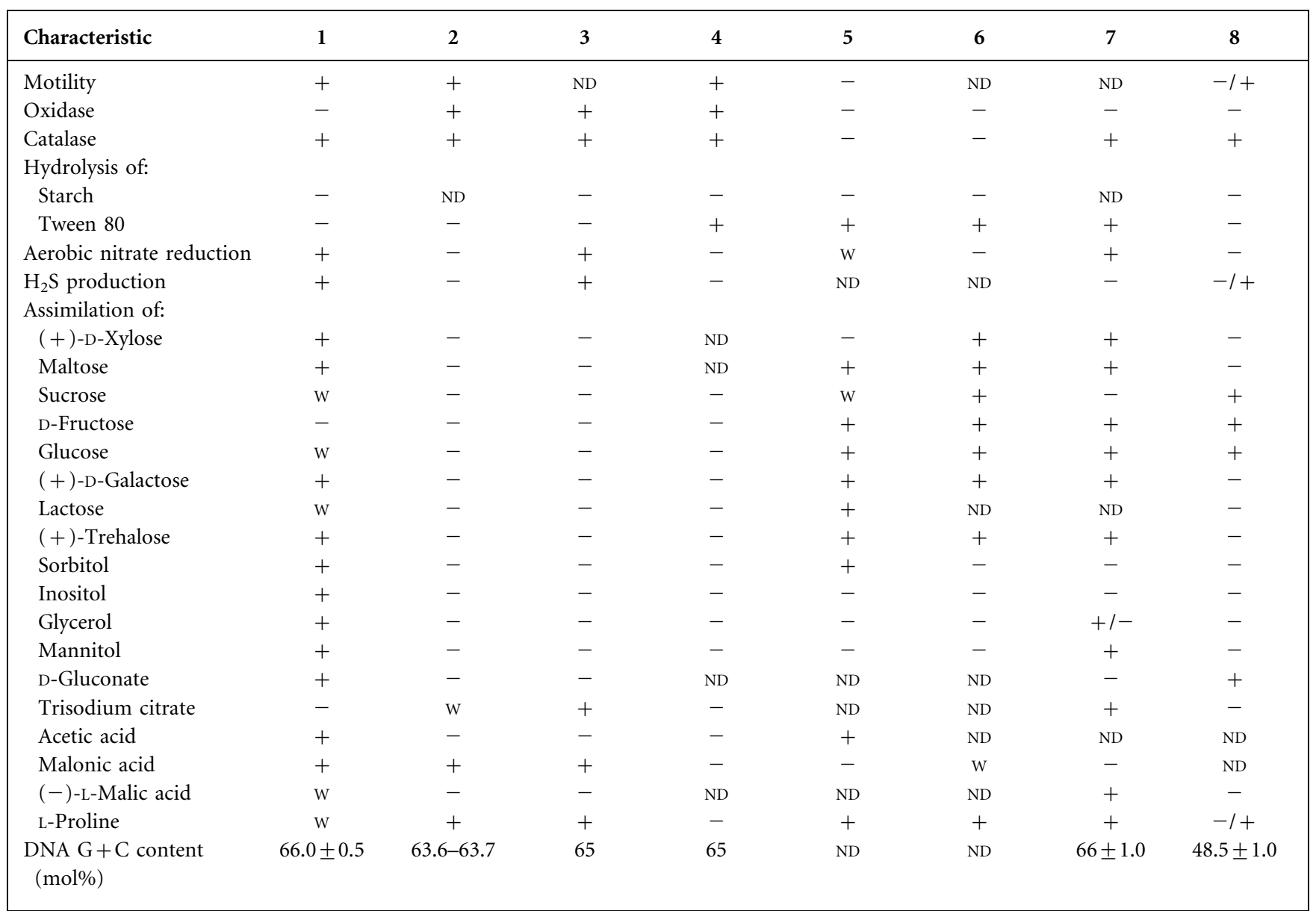


quinone. Cellular fatty acids were $\mathrm{C}_{18: 1} \omega 7 c(72.88 \%)$, $\mathrm{C}_{14: 0} 2-\mathrm{OH}(11.93 \%), \mathrm{C}_{16: 0}(11.53 \%), \mathrm{C}_{18: 1} \omega 5 c(2.02 \%)$ and $\mathrm{C}_{16: 1} \omega 7 c(1.64 \%)$ (Supplementary Table $\mathrm{S} 1$ ).

The DNA G + C content of JLT $832^{\mathrm{T}}$ was $66 \pm 0.5 \mathrm{~mol} \%$. The complete $16 \mathrm{~S}$ rRNA gene sequence $(1412 \mathrm{bp})$ of strain JLT832 ${ }^{\mathrm{T}}$ was determined. Phylogenetic trees based on $16 \mathrm{~S}$ rRNA gene sequences (1374 bp compared) showed that strain JLT832 ${ }^{\mathrm{T}}$ forms a distinct phylogentic lineage within the family Sphingomonadaceae (Fig. 1) and exhibits the highest sequence similarity to Novosphingobium subarcticum SMCC B0478 $(94.9 \%)$, followed by Novosphingobium mathurense SM $117^{\mathrm{T}}(94.3 \%)$ and Sphingosinicella microcystinivorans JCM $13185^{\mathrm{T}}$ (94.3\%).

No currently recognized species in the genera Novosphingobium, Sphingosinicella and Zymomonas utilize sorbitol except Novosphingobium panipatense and N. subarcticum. N. subarcticum only utilized mannitol, while strain JLT832 could utilize sorbitol, mannitol, myo-inositol and glycerol.

A comparison of differential characteristics of strain $\mathrm{JLT} 832^{\mathrm{T}}$ and members of related genera Novosphingobium, Sphingosinicella and Zymomonas are listed in Table 1. The morphological, physiological and biochemical characteristics of strain JLT832 ${ }^{\mathrm{T}}$ indicate that the new isolate represents a novel genus and species of the family Sphingomonadaceae, for which the name Stakelama pacifica gen. nov., sp. nov. is proposed.

\section{Description of Stakelama gen. nov.}

Stakelama (Sta.ke.la'ma. N.L. fem. n. Stakelama arbitrary name derived from State Key Laboratory of Marine Environment Science).

Cells are Gram reaction-negative, weakly motile, nonspore-forming rods. Colonies are gold-yellow. Strictly aerobic. Positive for catalase and negative for oxidase. The major fatty acids are $\mathrm{C}_{18: 1} \omega 7 c, \mathrm{C}_{14: 0} 2-\mathrm{OH}$ and $\mathrm{C}_{16: 0}$. The sole respiratory quinone is Q-10. The DNA G+C content of the type strain of the type species is $66 \pm 0.5 \mathrm{~mol} \%$. The type species is Stakelama pacifica.

\section{Description of Stakelama pacifica sp. nov.}

Stakelama pacifica (pa.ci'fi.ca. L. fem. adj. pacifica peaceful, referring to the Pacific Ocean, the origin of the type strain).

The following properties are shown in addition to those given in the genus description. Cells are $0.5-0.8 \times 1.5-$ $2.0 \mu \mathrm{m}$, and have a flagellum. Colonies on RO medium are circular, slightly raised, smooth and $1 \mathrm{~mm}$ in diameter after incubation for $24 \mathrm{~h}$ at $28{ }^{\circ} \mathrm{C}$. Growth occurs at 5$37{ }^{\circ} \mathrm{C}$ (optimum $28{ }^{\circ} \mathrm{C}$ ), $\mathrm{pH} 6-9$ (optimum $\mathrm{pH}$ 8) and in

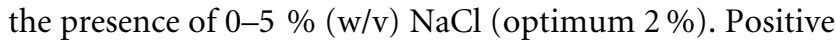
for catalase, aerobic nitrate reduction, $\mathrm{H}_{2} \mathrm{~S}$ production and the VP reaction. Negative for oxidase, urease, aerobic nitrite reduction, anaerobic nitrate reduction, indole production, the MR test and hydrolysis of gelatin, starch, Tween 80 and casein. (+)-D-Xylose, maltose, sorbitol, lactose, (+)-trehalose, cellobiose, lactic acid, sodium Dgluconate, inositol, glycerol, mannitol, acetic acid, ethanol and malonic acid are utilized. Sucrose, glucose, $(+)$-Dgalactose, (-)-L-malic acid, L-proline and L-threonine are used weakly. (-)-L-Sorbose, D-fructose, dextrin, trisodium citrate, oxalic acid, L-alanine, L-lysine, glycine and Larginine are not utilized. The type strain was sensitive $(\mu \mathrm{g}$ per disc) to ampicillin (10), penicillin (10), tetracycline (30), chloramphenicol (30), erythromycin (15), cefoperazone (75), cefotaxime (30), ciprofloxacin (5), clarithromycin (15), gentamicin (120) and streptomycin (300); resistant to clindamycin (2), sulfamethoxazole (300), vancomycin (30) and cefalothin (30).

The type strain, $\mathrm{JLT} 832^{\mathrm{T}}$ (=CGMCC $1.7294^{\mathrm{T}}=\mathrm{LMG}$ $24686^{\mathrm{T}}$ ), was isolated from surface water at $174^{\circ} 21.70^{\prime} \mathrm{E}$ $20^{\circ} 34.44^{\prime} \mathrm{N}$ in the Pacific Ocean.

\section{Acknowledgements}

The authors would like to thank Dr Hans-Jürgen Busse, Institut für Bakteriologie, Mykologie und Hygiene, University of Veterinary Medicine Vienna, for the analysis of the polyamine pattern. This work was supported by the MOST 973 project (2007CB815904), the NSFC projects (40632013 and 40821063), the SOA project (200805068) and the COMRA project (DYXM-115-02-4-3).

\section{References}

Altschul, S. F., Gish, W., Miller, W., Myers, E. W. \& Lipman, D. J. (1990). Basic local alignment search tool. J Mol Biol 215, 403-410.

Andrews, J. M. (2008). BSAC standardized disc susceptibility testing method (Version 7). J Antimicrob Chemother 62, 256-278.

Bruns, A., Rohde, M. \& Berthe-Corti, L. (2001). Muricauda ruestringensis gen. nov., sp nov., a facultatively anaerobic, appendaged bacterium from German North Sea intertidal sediment. Int J Syst Evol Microbiol 51, 1997-2006.

Busse, H.-J. \& Auling, G. (1988). Polyamine pattern as a chemotaxonomic marker within the Proteobacteria. Syst Appl Microbiol 11, 1-8.

Busse, H. J., Kämpfer, P. \& Denner, E. B. (1999). Chemotaxonomic characterisation of Sphingomonas. J Ind Microbiol Biotechnol 23, 242251.

Cappuccino, J. G. \& Sherman, N. (2002). Microbiology: a Laboratory Manual, 6th edn. San Francisco: Pearson Education, Inc. and Benjamin Cummings.

De Ley, J. \& Swings, J. (1976). Phenotypic description, numerical analysis and a proposal of an improved taxonomy and nomenclature of the genus Zymomonas Kluyer and van Niel 1936. Int J Syst Bacteriol 26, 146-157.

Denner, E. B., Paukner, S., Kämpfer, P., Moore, E. R., Abraham, W.-R., Busse, H.-J., Wanner, G. \& Lubitz, W. (2001). Description of Sphingomonas pituitosa sp. nov., a novel polysaccharide-producing sphingomonad. Int J Syst Evol Microbiol 51, 827-841.

Dong, X.-Z. \& Cai, M.-Y. (2001). Determinative Manual for Routine Bacteriology. Beijing: Scientific Press (in Chinese).

Drews, G. (1983). Mikrobiologisches Praktikum. Berlin, Germany: Springer (in German).

Fraser, S. L. \& Jorgensen, J. H. (1997). Reappraisal of the antimicrobial susceptibilities of Chryseobacterium and Flavobacterium species and 
methods for reliable susceptibility testing. Antimicrob Agents Chemother 41, 2738-2741.

Gerhardt, P., Murray, R. G. E., Wood, W. A. \& Krieg, N. R. (editors) (1994). Methods for General and Molecular Bacteriology. Washington, DC: American Society for Microbiology.

Geueke, B., Busse, H.-J., Fleishmann, T., Kämpfer, P. \& Kohler, H.-P. E. (2007). Description of Sphingosinicella xenopeptidilytica sp. nov., a $\beta$ peptide-degrading species, and emended descriptions of the genus Sphingosinicella and Sphingosinicella microcystinivorans. Int J Syst Evol Microbiol 57, 107-113.

Gupta, S. K., Lal, D. \& Lal, R. (2009). Novosphingobium panipatense sp. nov. and Novosphingobium matheurense sp. nov., from oil-contaminated soil. Int J Syst Evol Microbiol 59, 156-161.

Hamana, K., Sakamoto, A., Tachiyanagi, S., Terauchi, E. \& Takeuchi, M. (2003). Polyamine profiles of some members of the alpha subclass of the Proteobacteria: polyamine analysis of 20 recently described genera. Microbiol Cult Coll 19, 13-21.

Hiraishi, A., Ueda, Y. \& Ishihara, J. (1998). Quinone profiling of bacterial communities in natural and synthetic sewage activated sludge for enhanced phosphate removal. Appl Environ Microbiol 64, 992-998.

Hu, Y.-T., Zhou, P.-J., Zhou, Y.-G., Liu, Z.-H. \& Liu, S.-J. (2004). Xaccharothrix xingjiangensis sp. nov., a pyrene-degrading actinomycete isolated from Tianchi Lake, Xinjiang, China. Int J Syst Evol Microbiol 54, 2091-2094.

Johnson, J. L. (1994). Similarity analysis of DNAs. In Methods for General and Molecular Bacteriology, pp. 655-681. Edited by P. E. Gerhardt, R. G. Murray, W. A. Wood \& N. R. Krieg. Washington, DC: American Society for Microbiology.

Kosako, Y., Yabuuchi, E., Naka, T., Fujiwara, N. \& Kobayashi, K. (2000). Proposal of Sphingomonadaceae fam. nov., consisting of Sphingomonas Yabuuchi et al. 1990, Erythrobacter Shiba and Shimidu 1982, Erythromicrobium Yurkove et al. 1994, Porphyrobacter Fuerst et al. 1993, Zymomonas Kluyver and van Niel 1936, and Sandaracinobacter Yurkove et al. 1997, with the type genus Sphingomonas Yabuuchi et al. 1990. Microbiol Immunol 44, 563-575.

Kumar, S., Tamura, K. \& Nei, M. (2004). MEGA3: Integrated software for molecular evolutionary genetics analysis and sequence alignment. Brief Bioinform 5, 150-163.

Lee, K.-B., Liu, C.-T., Anzai, Y., Kim, H., Aono, T. \& Oyaizu, H. (2005). The hierarchical system of the 'Alphaproteobacteria': description of Hyphomonadaceae fam. nov., Xanthobacteraceae fam. nov. and Erythrobacteraceae fam. nov. Int J Syst Evol Microbiol 55, 19071919.

Lim, Y. W., Moon, E. Y. \& Chun, J. (2007). Reclassification of Flavobacterium resinovorum Delaporte and Daste 1956 as Novosphingobium resinovorum comb. nov., with Novosphingobium subarcticum (Nohynek et al. 1996) Takeuchi et al. 2001 as a later heterotypic synonym. Int J Syst Evol Microbiol 57, 1906-1908.

Marmur, J. (1961). A procedure for the isolation of deoxyribonucleic acid from microorganisms. J Mol Biol 3, 208-218.
Marmur, J. \& Doty, P. (1962). Determination of the base composition of deoxyribonucleic acid from thermal denaturation temperature. J Mol Biol 5, 109-118.

Maruyama, T., Park, H.-D., Ozawa, K., Tanaka, Y., Sumino, T., Hamana, K., Hiraishi, A. \& Kato, K. (2006). Sphingosinicella microcystinivorans gen. nov., sp. nov., a microcystin-degrading bacterium. Int J Syst Evol Microbiol 56, 85-89.

Minnikin, D. E., O'Donnell, A. G., Goodfellow, M., Alderson, G., Athalye, M., Schaal, A. \& Parlett, J. H. (1984). An integrated procedure for the extraction of bacterial isoprenoid quinones and polar lipids. J Microbiol Methods 2, 233-241.

Nohynek, L. J., Nurmiaho-Lassila, E.-L., Suhonen, E. L., Busse, H.-J., Mohammadi, M., Hantula, J., Rainey, F. \& Salkinoja-Salonen, M. S. (1996). Description of chlorophenol-degrading Pseudomonas sp. strains $\mathrm{KF}^{\mathrm{T}}, \mathrm{KF} 3$ and NKF1 as a new species of the genus Sphingomonas, Sphingomonas subarctica sp. nov. Int J Syst Bacteriol 46, 1042-1055.

Rainey, F. A., Ward-Rainey, N., Kroppenstedt, R. M. \& Stackebrandt, E. (1996). The genus Nocardiopsis represents a phylogenetically coherent taxon and a distinct actinomycete lineage: proposal of Nocardiopsaceae fam. nov. Int J Syst Bacteriol 46, 1088-1092.

Romano, I., Lama, L., Nicolaus, B., Poli, A., Gambacorta, A. \& Giordano, A. (2006). Halomonas alkaliphila sp. nov., a novel halotolerant alkaliphilic bacterium isolated from a salt pool in Campania (Italy). J Gen Appl Microbiol 52, 339-348.

Stolz, A., Busse, H.-J. \& Kämpfer, P. (2007). Pseudomonas knackmussii sp. nov. Int J Syst Evol Microbiol 57, 572-576.

Swings, J. \& De Ley, J. (1977). The biology of Zymomonas. Bacteriol Rev 41, 1-46.

Takeuchi, M., Hamana, K. \& Hiraishi, A. (2001). Proposal of the genus Sphingomonas sensu stricto and three new genera, Sphingobium, Novosphingobium and Sphingopyxis, on the basis of phylogenetic and chemotaxonomic analyses. Int J Syst Evol Microbiol 51, 1405-1417.

Williams, S. T., Goodfellow, M., Alderson, G., Wellington, E. M. H., Sneath, P. H. A. \& Sackin, M. J. (1983). Numerical classification of Streptomyces and related genera. J Gen Microbiol 129, 1743-1813.

Yabuuchi, E., Yano, I., Oyaizu, H., Hashimoto, Y., Ezaki, T. \& Yamamoto, H. (1990). Proposals of Sphingomonas paucimobilis gen. nov. and comb. nov., Sphingomonas parapaucimobilis sp. nov., Sphingomonas yanoikuyae sp. nov., Sphingomonas adhaesiva sp. nov., Sphingomonas capsulata comb. nov., and two genospecies of the genus Sphingomonas. Microbiol Immunol 34, 99-119.

Yoon, J.-H., Kang, S.-J., Lee, J.-S., Nam, S.-W., Kim, W. \& Oh, T.-K. (2008). Sphingosinicella soli sp. nov., isolated from an alkaline soil in Korea. Int J Syst Evol Microbiol 58, 173-177.

Yurkov, V. V., Krieger, S., Stackebrandt, E. \& Beatty, J. T. (1999). Cirtomicrobium bathyomarinum, a novel aerobic bacterium isolated from deep-sea hydrothermal vent plume waters that contains photosynthetic pigment-protein complexes. J Bacteriol 181, 4517-4525.

Zumft, W. G. (1992). The denitrifying bacteria. In The Prokaryotes, 2nd edn. pp. 554-582. Edited by A. Balows, H. G. Trüper, M. Dworkin, W. Harder \& K. H. Schleifer. New York: Springer Verlag. 